Article

\title{
Determinants of Enterprises Radical Innovation and Performance: Insights into Strategic Orientation of Cultural and Creative Enterprises
}

\author{
Tsui-Yii Shih
}

Department of International Business, National Taipei University of Business, Jinan Road, Zhongzheng District, Taipei City 100, Taiwan; tsuiyii@ntub.edu.tw or trace@ms16.hinet.net

Received: 23 April 2018; Accepted: 31 May 2018; Published: 4 June 2018

check for updates

\begin{abstract}
A firm's strategic orientation determine its business direction and scope of operation. Several researchers have tried to identify how strategic orientations affect business development. However, only a few scholars have explored how strategic orientations shape a firm's organizational capability. In addition, the extent to which radical innovation contributes to a firm's operations has not been well researched. Given these research shortcomings, this study explores the integration of firms' strategic orientations, radical innovation, competitive advantages, and business performance within a conceptual framework. A sample of 86 cultural and creative firms was obtained. The results of the regression analysis and of the PLS SEM model are compared in this study. Our findings suggest that factors from either market orientation or entrepreneurial orientation add to a firm's radical innovation capability and adoption. Lastly, the brand advantage is identified to be the most important factor in firms' performance after a radical innovation capability and product advantage. This paper offers several contributions to the research. First, it advances knowledge of the strategic orientations of cultural and creative firms in a developing market. Second, it demonstrates the usefulness of radical innovation capability in profiling the development of competitive advantages. Lastly, it adds to our understanding of factors that facilitate the business performance of cultural and creative entrepreneurs.
\end{abstract}

Keywords: strategic orientation; radical innovation; competitive advantage; cultural and creative

\section{Introduction}

A business strategy provides the theoretical basis for firms to achieve a competitive advantage in order to surpass their competitors. For instance, a firm's business strategy may help it attain a cost advantage (in terms of high productivity levels, good bargaining power, use of improved technology in the production process, etc.) or a differentiation advantage (by offering value-added features, superior product quality, branding, etc.) [1,2]. Using the resource-based view (RBV) theory, a firm can exploit its resources (tangible or intangible) and capabilities (e.g., innovation capability) to create a competitive advantage and achieve superior value creation $[1,2]$. The improved arrangement of resources and capabilities is an important advantage for enterprises to survive in commercial markets [3-5]. Therefore, the business strategy theory and resource-based viewpoints (RBV, see Barney [6]) offer an avenue for researchers to explore strategic management in enterprises and their development of resources and capabilities to cultivate a competitive advantage. For instance, based on past research in the strategy domain, Saranga et al. [7] investigated how an interaction between resources underlying an important capability can lead to various degrees of the competitive advantage. Therefore, by being rooted in the business strategy theory and using an RBV, it is possible to identify the relationships and interactive links among the strategy, resources, and capabilities as well as 
the resultant competitive advantage within various business practices. Hill et al. [2] note that the innovation capability is one of the most important generic building blocks required to enhance a firm's competitive advantage. In practice, numerous enterprises emphasize innovation capability and expect to successfully integrate it into business processes, products, and services. For instance, from the emergence of virtual enterprises such as AirBnB, Facebook, WeChat, LINE, and more, these companies develop new commercial models and change consumer behavior. These first movers in virtual business platforms fully apply radical innovation features. Currently, innovation and creativity are usually adopted by enterprises when formatting new business models and then firms expect to increase their operation or international performance. However, it remains unclear as to how to incorporate innovation capability into organizational culture and the working environment. Accordingly, we treat innovation capability as the key dimension when conducting the framework and look to identify its interactive effects among independent and dependent dimensions in our conceptual model.

Within the academic literature, based on the viewpoints from strategy theory and RBV, Salavou and Lioukas [8] and Chang et al. [9] conduct studies and identify how a firm's strategic orientation affects the developments of product innovations. Slater, Mohr, and Sengupta [10] prove that the strategic intent of senior leadership, organizational culture (e.g., customer orientation, technological orientation, competitor orientation, and learning orientation) and organizational structure (e.g., cross-functional integration, reliance on suppliers or distributors, etc.) have a significant effect on an enterprise's capability for radical innovation. Ground theory or NPD (new product development) theory is usually referenced and utilized by researchers to conduct studies and identify innovation capability, processing [11], or scopes (e.g., open innovations) [12,13]. Story et al. [14] indicate that successful launches of radical innovations enable the understanding of mutually beneficial relationships with stakeholders and these help create a clear product advantage. The innovation capability may result in product advantage, brand value [15,16], or sales growth [17]. However, firms' return of assets (ROA) cannot be enhanced effectively through innovation capability [17]. Therefore, despite the high risk from innovation adoption, these studies in the literature show that the innovation capability of enterprises has been proven to increase advantages in product, brand, and firms' reputation. The above reviews have displayed the predisposing factors (e.g., strategic orientations) and benefits (e.g., competitive advantages or business performance) when exploring and discussing enterprises' radical capability development or adoption.

In general, innovation methods are commonly divided into two broad types including radical innovation and incremental innovation $[13,15]$. Since its specific features differ, innovations adopted by firms drive different operating performances $[18,19]$. In this study, the creative features of cultural and creative firms, rather than those of general commodity industries, and radical innovation are the subjects of our focus. When discussing the antecedents of radical innovation, researchers have contended that the strategic orientations of enterprises are important factors in the level of firm innovation capability and adoption. For instance, Salavou and Lioukas [8] and Lassen, Gertsen, and Riis [20] show that entrepreneurial orientated enterprises are dominated by radical innovation. A market orientated enterprise displays either a positive [21] or non-significant role for radical innovation [8]. These findings are inconsistent and scholarly comparisons of the two strategic orientations remain limited. Furthermore, in addition to discussing the antecedents of radical innovation, the benefits of radical innovation adoption and capability for enterprises are also a concern of managers and researchers. According to Yu [22], radical innovation implies commercialization and commercialization should lead to financial performance [21]. Through new product performance, Chang et al. [9] found that radical innovation influences firm performance. Therefore, the competitiveness of the product itself is critical since it mediates the effects of radical innovation on firm performance. Radical innovation has been shown to affect a firm's competitive advantage (for product advantages, see Chang et al. [9]; for quality, corporate image and profitability, see Chang [23]) and to add improved brand or value equity in comparison to incremental innovation [1]. In the culture and creative industry (hereafter referred to as the $C \& C$ industry), there are numerous 
factors that can enhance firm performance. This includes product, brand, relationships, and management advantages. This study considers product and brand advantage as two particularly important factors for a firm's operational performance. The present study, therefore, integrates strategic orientations in constructing a framework to identify the determinants of a firm's radical innovation and further links radical innovation to competitive advantages and business performance via $C \& C$ industry practices.

According to Digital, Culture, Media and Sport (DCMS) [24], a creative industry is an industry which has its origins in individual creativity, skills, and talent. Through the development of intellectual property, this industry has the potential to generate wealth and increase job creation. Creative industries include those dealing with advertising, antiques, crafts, fashion, design, film, performing arts, music, leisure software, software [24], publishing, visual arts, television, and radio [25]. Hesmondhalgh [26] further adds marketing, the Internet, and computer games into the scope of cultural industries. In Taiwan, the cultural and creative industry covers a broad area, which is similar to DCMS's [24] definition. The C\&C industry is seen as an industry that originates from creative or cultural accumulation through the formation and application of intellectual property and has the potential to enhance our living environment [27]. Presently, SMEs in the C\&C industry are seeking global market opportunities more energetically and efficiently than in the past. Among them, more C\&C SMEs are participating in international activities through physical channels (e.g., direct stores, creative markets, etc.) or by means of virtual platforms (e.g., virtual C\&C platforms). In terms of business strategy theory, RBV, ground theory, and NPD, the present study addresses this problem by discussing two strategic orientations including radical innovation and competitive advantages (defined as product advantage and brand advantage) and business performance. The remainder of this research is organized in the following sections. The literature and hypotheses are reviewed, followed by the research methodology, and the data analysis is reported. The study concludes with the management implications, theory contributions, and future research suggestions.

\section{Literature Review}

A review of literature shows that researchers have previously immersed themselves in attempting to understand the strategy orientation-innovation-competitive advantage-performance relationships, respectively. Based on business strategy theory, RBV, ground theory, and NPD, a variety of academic perspectives and frameworks have been explored in the field such as strategic orientations $[8,20,21]$, the theory of innovation capability $[9,22]$, a competitive advantage perspective $[9,23]$, and business performance $[9,21,22]$. Such approaches obscure our understanding of the evolution of the above factors as interactive networks. The following section adds more discussions for model development.

\subsection{Strategic Orientations and Radical Innovation}

According to Chou [28], strategic orientation helps a firm create the appropriate actions and behaviors required for obtaining and sustaining superior performance. It is the drivers of enterprises' technological innovation and leads to a competitive advantage [28] and business performance. Regarding strategic orientation of enterprises, researchers identify and develop its measurement scales in terms of different viewpoints. Strategic orientations have been shown to affect firms' innovation adoption [19]. The major types of strategic orientations discussed by researchers include market orientation and entrepreneurial orientation [8,29]. For instance, Naidoo [18] indicated that market orientation determines firms marketing innovation. Entrepreneurial orientation generates innovation adoption and capability [20]. In the academic world, market orientation is defined as comprehending and satisfying the needs or demands of customers and other relevant stakeholders (e.g., suppliers, distributors, competitors, government, environment groups, etc.) [30]. Scales for measuring market orientation include customer orientation, competitor orientation, and inter-functional coordination [18]. According to researchers, customer orientation means a firm primarily aims to anticipate and satisfy customer needs. Under competitor orientation, a firm will closely analyze and monitor the strategic 
intent and tactical moves of their competitors [31]. Inter-functional coordination is defined as the coordination of different departments in an organization in order to satisfy customer needs and monitor competitor actions [32]. A firm that possesses a market orientation serves its customers by providing products that best fit those customers' needs [33] and makes the effort to learn and find innovation from customers, competitors, and the external market environment [34]. In this study, we adopt customer orientation [26,31], competitor orientation [31], and inter-functional coordination [32,35] to measure managers' perceptions towards firms' market orientation levels.

The concept of entrepreneurial orientation was first proposed by Miller and Friesen in 1982 [36]. According to Lassen et al. [20], entrepreneurial orientation has four dimensions including being proactive, taking risks, autonomy, and competitive aggressiveness. Firms with an entrepreneurial orientation emphasize innovative activity and possess a greater willingness to take risks and engage in proactive market leadership. Competitive aggressiveness represents the intensity, posture, or direction of a firm's efforts to outperform industry competitors or prevail over the actions of their rivals [37]. Risk taking is the willingness to make large resource commitments to seize high return opportunities in the marketplace [38]. Being proactive means taking the initiative by pursuing new opportunities and by taking advantages of emerging markets [38]. Considering autonomy is a general characteristic among enterprisers in C\&C industries. In this study, entrepreneurial orientation is measured in terms of three sub dimensions including competitive aggressiveness [37,38], risk taking [38,39], and proactiveness $[39,40]$.

Researchers have explored the effects of firms' strategic orientations on their innovation capability with conflicting findings. Li, Lin, and Chu [41] and Cai et al. [42] find proactive and responsive market orientation assisting radical innovation by firms. Market orientation (clients' orientation, competitors' orientation, and inter-functional coordination) [43] and corporate culture (willingness to cannibalize, future market orientation, and risk tolerance) [21] positively determine radical innovation levels [44]. An entrepreneurial orientation provides a key avenue for an enterprise in transferring innovation to the markets [45] and positively driving its performance [46]. Firms with an entrepreneurial orientation (proactiveness, risk taking, autonomy, competitive aggressiveness, see Salavou and Lioukas [8]) have enhanced radical innovation capability [20]. However, some researchers show that market orientation is less useful than an entrepreneurial orientation [8,41]. Accordingly, the various approaches for the explanation of the innovation capabilities of the firm provide different emphases on the issue of firms' strategic orientations. This inconsistency is useful in obtaining insights grounded in a synthesis of the research. In order to identify and compare the influence of market orientation and entrepreneurial orientation on C\&C firms' radical innovation levels, the following hypotheses are constructed below.

Hypothesis 1 (H1). Within the CEC industry, perceived market orientations have a significant and positive effect on a CEC firm's radical innovation level.

Hypothesis 2 (H2). Within the CEC industry, perceived entrepreneurial orientations have a significant and positive effect on a CEC firm's radical innovation level.

\subsection{Radical Innovation and Firms Competitive Advantage and Performance}

Researchers have shown that firm innovation contributes to both their business and management operations. The dual categorization of innovation as either incremental (technological changes are minor and the incremental benefit to customers is low) or radical (adopting new technology and providing greater benefit to customers) is among the most embedded in the literature reviewed [18,47-50]. According to OECD [51], incremental innovation is the dominant form of innovation. It is concerned with how to effectively enhance or upgrade the performance of an existing product, service, process, organization, or method. Radical innovation is a complex process that implies a difficult, lengthy, and risky process and one that has a significant impact on the economic activity of firms in that market [52]. Incremental innovations continuously seek to improve their 
targets (e.g., services, products, methods, process, etc.), whereas radical innovations create major changes to targets (e.g., business models, market types, etc.) [52]. SMEs or new market entrants usually play distinct roles in introducing radical innovations [51]. Considering the creative and innovative features of the $C \& C$ industry and that most $C \& C$ firms belong to SMEs, this study selected radical innovation as its research target. According to researchers, radical innovation is identified as the fundamental change in new products or services. As such, it represents revolutionary changes in technology [53]. The changes obviously depart from current knowledge and require a high degree of additional knowledge [47]. As a result, there is greater uncertainty, less standardization of physical and human capital, and a more transaction-unique innovation than with incremental innovation [49].

A few scholars have defined innovation as a moderating variable between market orientation and performance [54]. Wu et al. [19] verified that value creation is largely supported by innovative capabilities. However, some researchers find that innovation does not directly stir a firm's performance [9]. Naidoo [18] argues that the relationship between innovation and performance is mediated by a firm's competitive advantage. Radical innovation is identified as the main ingredient of a competitive advantage [55]. Radical innovations create a competitive advantage through the opening of new markets and through the generation of changes in consumer preferences [56]. This means that a firm's radical innovativeness enables it to develop creative and differing products [21], to increase its value equity and brand equity [15], and to transcend its industrial competitors. High levels of radical innovation could help sustain a firm's ability to build intangible resource advantages (brand image and reputation) [57]. Furthermore, radical innovations have been proven to affect firm performance. Firms who promote the generation of radical innovations for developing their activities may increase their performance in the marketplace [58]. However, some empirical findings regarding the value of a firm's radical innovativeness, are conflicting. Performance outcomes of innovation may be positive [21,22], negative [59], or unrelated [60]. Consequently, the review results display that radical innovation may affect performance directly [54] or influences a firm's performances via the mediating effects of improvements and applications of competitive advantages [15,18,21,57]. In this study, the question items of radical innovation are drawn from Cheng and Shiu [61]. The levels of radically new features and changes in products are evaluated by the $C \& C$ firm managers by comparing with competitors.

To recognize and measure business performance, researchers use a variety of objective indicators (e.g., ROE, ROA, financial ratios, etc.) or subjective attitudes (e.g., managers' satisfaction, experiences, etc.) [62-64]. In practice, some respondents prefer to avoid disclosing a firm's financial data. Furthermore, in Taiwan, some SMEs are reluctant to discuss their financial information with the public. This behavior makes it difficult to discover Taiwanese C\&C firms' objective financial situations. Therefore, for measuring business performance, this study adopts subjective attitude items from Lau et al. [65] and Kim et al. [66]. We invited target $C \& C$ firms' respondents to evaluate the performance of their C\&C firm's sales goals, profit goals, and profit and sales compared to those of competitors. This study, therefore, discusses the effects of firms' radical innovation levels on a competitive advantage (product advantage and brand advantage) and performance. The following hypotheses are constructed:

Hypothesis 3 (H3). Within the CEC industry, perceived radical innovation has a significant and positive effect on a CEC firm's product advantage.

Hypothesis 4 (H4). Within the CEC industry, perceived radical innovation has a significant and positive effect on a CEC firm's brand advantage.

Hypothesis 5 (H5). Within the CEC industry, perceived radical innovation has a significant and positive effect on a CEC firm's business performance. 


\subsection{Competitive Advantage and Firm Performance}

Competitive advantage means the ability of a firm to build a defensible position to surpass its competitors [1]. Several researchers discuss the relationship between a firm's competitive advantage and its performance in various industries $[67,68]$. Firms' competitive advantages enables them to transform themselves in order to bridge gaps that competitors find difficult to cross and devote these changes toward improved business performance [18]. According to a review of the literature, many scholars have explored cost advantages and different advantages [1,2]. Numerous researchers examine the methods to achieve these two advantages by offering several practical findings for enterprises who want to attain them. Moreover, researchers have also looked at core competences and competitive advantages generated from resource and capability as identified by RBV theory [6]. In terms of the resource-based view (RBV), a firm may build a managerial framework to align its strategic resources. Resources and capabilities can also be exploited by firms in order to achieve sustainable competitive advantages. This study focuses on competitive advantages as the firms' output of radical innovation. Through the findings of researchers using ground theory or NPD, the major contributions of a radical innovation capability adopted by enterprises include product or service advantages, brand value, or growth in customers' purchase volume. According to Nayyar [3], the competitive advantages of firms may comprise brand identification, reputation, partner relationships, and customer loyalty. Bharadwaj et al. [4] suggested that the major sources of a firm's competitive advantage may include scale, product, brand equity, information technology, and customer service related skills [5]. Furthermore, several studies have concentrated on resource advantages such as product advantage $[9,68]$ and brand advantage $[15,29]$ within the industry context and have examined their effects on firm success [69]. According to Hua and Wemmerlöv [70], radical changes to product architecture tend to result in the increased attraction of products in consumer markets as compared with minor changes to product features. The radical innovation capability is helpful to ensure a product advantage for firms.

In an industrial practice, the product is a core element of a firm's brand value [71]. First, product attributes are a key factor in building customer brand preference [72]. Second, product advantages tend to enhance the market performance of firms [70]. Lastly, sustainable brands have been found to have highly significant mediation effects and direct effects on the improvement of business performance [73]. By integrating the viewpoints of the above researchers, this research selects product and brand advantages as the basis for the development of competitive advantage items and explores their effects on C\&C firms' performance. The effects of product advantage on $C \& C$ enterprise brand advantage are also discussed [71,72]. For product advantages, question items from Kam-Sing Wong [74] are used. For Kam-Sing Wong [60], the unique features, superior level, technical performance, distinct benefits, and quality of products are evaluated by the firm respondents by comparing with their competitors. For brand advantage, items from Laukkanen et al. [29] are used. Using comparisons with their competitors, reputation, brand image, and brand loyalty are evaluated by C\&C firms' respondents. Accordingly, this study explores the effects of product and brand advantages on business performance and the effects of product advantage on brand advantage in $C \& C$ industrial practices. Hypotheses 6-8 are constructed below.

Hypothesis 6 (H6). Within the CEC industry, perceived product advantage has a significant and positive effect on a CEC firm's brand advantage.

Hypothesis 7 (H7). Within the CEC industry, perceived product advantage has a significant and positive effect on a CEC firm's business performance.

Hypothesis 8 (H8). Within the CEC industry, perceived brand advantage has a significant and positive effect on a CEC CEC firm's business performance. 


\section{Research Methodology}

\subsection{Industrial Background, Sampling, and Survey}

"Culture" is the sum of all human abilities and habits in a society including its social value system, life style, and spiritual life. In industrialized societies, the culture can aid and increase the value of people's lives, products, and services. In developed countries, the cultural and creative industry is both a developmental target and an indicator of the nation's overall economic and social development [75]. In Taiwan, the government has combined the two terms "culture" and "creativity" to form the term "Cultural \& Creative Industry" (CCI). In Taiwan, the C\&C industry may include visual arts, music, performing arts, cultural assets and exhibition, technology, movies, publishing, product design, brand fashion, creative life, adverting, architectural design, digital content, pop music and cultural content, and more [27]. In 2013, the government of Taiwan established five cultural and creative industrial parks (Huashan, Hualien, Taichung, Chiayi, and Tainan) to provide physical platforms for exhibitions, transactions, and cross-border cooperation among cultural and creative enterprisers [76]. These $C \& C$ industrial parks provided the data for the research. Furthermore, some virtual C\&C platforms (e.g., Pinkoi, uDesign, etc.) have emerged in Taiwan. For example, Pinkoi (see https://www.pinkoi.com/) has over 1.6 million members and provides more than 850,000 products. Over 8000 C\&C designers select Pinkoi as their virtual platforms because Pinkoi provides $C \& C$ designers to connect global markets. Currently, in Taiwan, a growing number of $C \& C$ firms offer products or services independently. Some are a hit with consumers and exhibit strong performance while others do not.

This study identifies key success factors for C\&C firms in Taiwan using a concept integrating several factors including strategic orientations [31,32,35,37-40], radical innovation [61], competitive advantages $[29,71]$, and business performance $[65,66]$. Figure 1 gives the conceptual framework of this study. The items on the questionnaire are first identified and designed based on the literature and are then modified to make them more appropriate for assessing manager attitudes (see Appendix A). Using translated and back translated methods, we assessed the items' readability and appropriateness. Items were measured using a 5-point Likert-type scale ( $1=$ strongly disagree, $5=$ strongly agree) toward targeted $C \& C$ firms' strategic orientations, radical innovation, competitive advantages, and performance. For obtaining respondent information from $\mathrm{C} \& \mathrm{C}$ firms, the major survey places were cultural and creative $(C \& C)$ industrial parks $(60 \%)$ and several $C \& C$ market towns (e.g., Yingge Ceramics Market in New Taipei City, etc.) (40\%). The research invited the targeted C\&C firms' respondents to answer the question items based on their firm's actual practices. Research assistants conducted the survey. The questionnaires were distributed to the sampling targets by face-to-face interviews (one respondent per firm). For respondents who directly refused to answer the questionnaires, gift incentives were offered. Phone interviews and mail were also used in the survey process to increase the valid response rate. In the survey process, firm respondents located in several C\&C markets or parks were contacted. Most of them directly or indirectly refused to respond to the survey after the study introduction by research assistants. Some $C \& C$ respondents answered the survey. However, a number of them didn't finish or couldn't answer some items listed in the questionnaire. Finally, 86 returned responses were valid. 


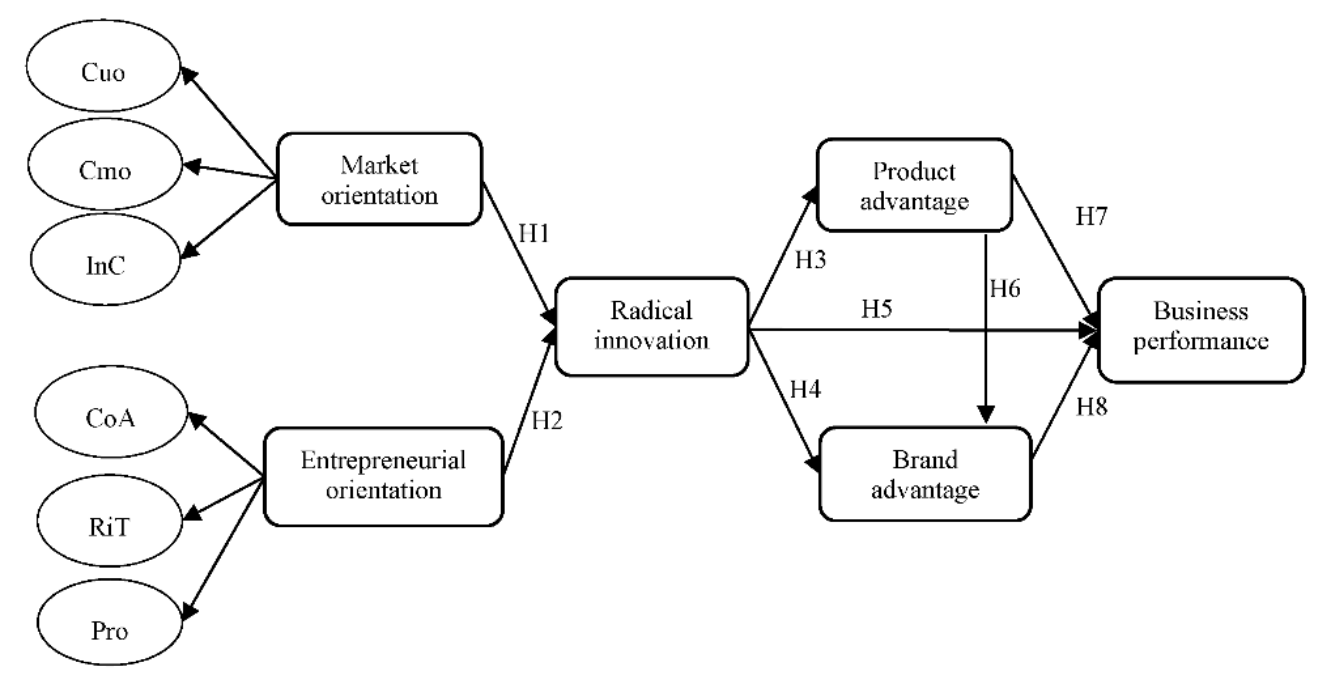

Figure 1. Research framework.

\subsection{Data Analysis Methods and Data Background}

In this study, data analysis methods include the use of descriptive statistics, factor and reliability analysis, correlation analysis, the linear regression method, and Smart PLS SEM methods. According to Chin and Newsted [77] and Cohen [78], a regression involving four independent variables would need a minimum sample size of 80. For instance, by applying regression analysis, Hua and Wemmerlöv [70] verify a study framework in terms of four factors and three paths by using data from 55 U.S. companies. For another aspect, partial least squares (PLS) are less stringent with the measurement scale type, sample size requirements, and distributional assumptions $[79,80]$ than Lisrel SEM techniques. The PLS path modeling method could solve small sample size problems and estimate very complex models with many latent and manifest variables [81]. A valid PLS model should have a minimum sample size 10 times the maximum number of paths for any constructs in the outer model and inner model [82]. For instance, Yoo and Alavi [83] conducted their research using a sample size of 45 groups in terms of the PLS method because there are five factors and six paths in their models. This present study adopts a second-order partial least squares (PLS) to reduce the number of variables and paths. Based on the research framework, the highest number of paths is eight (interdependent and dependent variables: radical innovation, product and brand advantages, and performance) and the second-order variables are six. The sample size of this study is 86 , which meets the regression method requirement 20 times the four independent variables (for classifying the different importance level of two strategic orientation variables on radical innovation factor) as well as the PLS requirement 10 times the maximum number of eight paths (for verifying the conceptual model).

Based on the questionnaires returned, the descriptive statistics presented as follows: $34.9 \%$ of the respondents are male and $65.1 \%$ female. In addition, $45.3 \%$ of the respondents are between 21 and 30 years old while $43 \%$ are between 31 and 40 years old. With regard to education distribution, $66.3 \%$ of the respondents have a university degree. Additionally, $79 \%$ have worked up to 1.5 years and $15 \%$ for more than six years. Work positions of $C \& C$ respondents include $C \& C$ designers $(26 \%)$, marketers $(18 \%)$, directors $(16 \%)$, managers, and senior employees. Furthermore, descriptive statistics of the responding $\mathrm{C} \& \mathrm{C}$ enterprises show the following business types. The business types of the surveyed $C \& C$ enterprises are product design, creative products, gift package, $C \& C$ clothing, brand fashion, and artistic products. Three $\mathrm{C} \& \mathrm{C}$ enterprises have been in existence for 25 years around $30 \%$ for less than five years and $33 \%$ of the responding enterprises has been in existence for six to 10 years. In sum, $63 \%$ of the firms have been in the Taiwanese C\&C market for less than 10 years. In addition, the number of employees of responding C\&C industry firms range from five to 1000 employees. 


\section{Data Analysis}

\subsection{Factor Analysis, Reliability, Discriminant Validity, and CMV Test}

All the indicators of the factors listed in Table 1 are generated by the PLS SEM factor analysis. Sub-factors of market orientation include customer orientation (Cuo), competitor orientation (Cmo), and inter-functional coordination (InC). The sub-factors of entrepreneurial orientation include competitive aggressiveness (CoA), risk taking (RiT), and proactiveness (Pro). For innovation type, this study focuses on radical innovation (RaI). The competitive advantage dimensions are product advantage (PrA) and brand advantage (BrA). The remaining dimension is business performance (BP). The results of the factor analysis and reliability analysis are listed in Table 1 . As Table 1 shows, all factor loadings of variables exceed 0.7 while the values for composite reliability exceed 0.8 and AVE values are greater than 0.5. Table 2 displays the second-order factor analysis of the full model. The convergence validity of the full model is also explored in Table 2. According to Table 2, the factor loadings for all variables and the values of their Cronbach's $\alpha$ exceeds 0.8 . The values of composite reliability of all factors also exceeds 0.8 . The AVE (average variances extracted) of all factors is over 0.4 , which provides strong support for the reliability of latent variables (see Table 2). These results offer strong evidence for construct reliability. These results offer strong evidence for construct reliability.

Table 1. Factor analysis, AVE, and convergence validity of the full model using the PLS SEM method.

\begin{tabular}{|c|c|c|c|c|c|c|c|}
\hline $\begin{array}{l}\text { Factor Names and } \\
\text { Question Items }\end{array}$ & $\begin{array}{l}\text { Factor } \\
\text { Loadings } \\
(t \text { Values) }\end{array}$ & AVE & $\begin{array}{c}\text { Cronbach } \\
\alpha\end{array}$ & $\begin{array}{l}\text { Composite } \\
\text { Reliability }\end{array}$ & Communality & $R^{2}$ & Redundancy \\
\hline \multicolumn{8}{|c|}{ Customer orientation $(\mathrm{Cuo})$} \\
\hline Cuo1 & $0.690(6.99)$ & \multirow{4}{*}{0.54} & \multirow{4}{*}{0.72} & \multirow{4}{*}{0.82} & \multirow{4}{*}{0.54} & \multirow{4}{*}{0.69} & \multirow{4}{*}{0.37} \\
\hline Cuo2 & $0.750(14.56)$ & & & & & & \\
\hline Cuo3 & $0.710(9.04)$ & & & & & & \\
\hline Cuo4 & $0.803(15.86)$ & & & & & & \\
\hline \multicolumn{8}{|c|}{ Competitor orientation $(\mathrm{Cmo})$} \\
\hline Cmo1 & $0.847(20.99)$ & \multirow{3}{*}{0.69} & \multirow{3}{*}{0.78} & \multirow{3}{*}{0.87} & \multirow{3}{*}{0.69} & \multirow{3}{*}{0.60} & \multirow{3}{*}{0.41} \\
\hline Cmo2 & $0.804(11.27)$ & & & & & & \\
\hline $\mathrm{Cmo3}$ & $0.852(30.59)$ & & & & & & \\
\hline \multicolumn{8}{|c|}{ Inter-functional coordination $(\operatorname{InC})$} \\
\hline $\mathrm{InC} 1$ & $0.826(18.18)$ & \multirow{4}{*}{0.72} & \multirow{4}{*}{0.87} & \multirow{4}{*}{0.91} & \multirow{4}{*}{0.72} & \multirow{4}{*}{0.73} & \multirow{4}{*}{0.53} \\
\hline $\mathrm{InC} 2$ & 0.867 (29.09) & & & & & & \\
\hline InC3 & $0.859(22.33)$ & & & & & & \\
\hline $\mathrm{InC} 4$ & $0.854(20.44)$ & & & & & & \\
\hline \multicolumn{8}{|c|}{ Competitive aggressiveness $(\mathrm{Co} A)$} \\
\hline CoA1 & $0.884(30.90)$ & \multirow{3}{*}{0.68} & \multirow{3}{*}{0.77} & \multirow{3}{*}{0.82} & \multirow{3}{*}{0.68} & \multirow{3}{*}{0.79} & \multirow{3}{*}{0.54} \\
\hline CoA2 & $0.839(26.90)$ & & & & & & \\
\hline CoA3 & $0.761(12.98)$ & & & & & & \\
\hline \multicolumn{8}{|l|}{ Risk taking $($ RiT) } \\
\hline RiT1 & $0.805(9.03)$ & & & & & & \\
\hline RiT2 & $0.815(19.94)$ & 065 & 082 & 088 & 065 & 083 & 054 \\
\hline RiT3 & $0.813(25.54)$ & 0.03 & 0.02 & 0.00 & 0.63 & 0.03 & 0.34 \\
\hline RiT4 & $0.795(14.04)$ & & & & & & \\
\hline Proactiveness (Pro) & & & & & & & \\
\hline Pro1 & $0.572(4.26)$ & & & & & & \\
\hline Pro2 & 0.648 (5.73) & & & & & & \\
\hline Pro3 & $0.819(21.06)$ & 0.54 & 0.72 & 0.82 & 0.54 & 0.77 & 0.41 \\
\hline Pro4 & $0.879(39.84)$ & & & & & & \\
\hline Radical innovation ( & & & & & & & \\
\hline RaI1 & $0.869(33.53)$ & & & & & & \\
\hline RaI2 & $0.863(25.24)$ & 0.75 & 0.83 & 0.90 & 0.93 & 0.54 & 0.40 \\
\hline RaI3 & $0.870(30.60)$ & & & & & & \\
\hline
\end{tabular}


Table 1. Cont.

\begin{tabular}{|c|c|c|c|c|c|c|c|}
\hline $\begin{array}{l}\text { Factor Names and } \\
\text { Question Items }\end{array}$ & $\begin{array}{c}\text { Factor } \\
\text { Loadings } \\
\text { ( } t \text { Values) }\end{array}$ & AVE & $\begin{array}{c}\text { Cronbach } \\
\alpha\end{array}$ & $\begin{array}{l}\text { Composite } \\
\text { Reliability }\end{array}$ & Communality & $R^{2}$ & Redundancy \\
\hline \multicolumn{8}{|c|}{ Product advantage $(\operatorname{Pr} A)$} \\
\hline PrA1 & $0.715(7.67)$ & \multirow{5}{*}{0.59} & \multirow{5}{*}{0.83} & \multirow{5}{*}{0.88} & \multirow{5}{*}{0.59} & \multirow{5}{*}{0.40} & \multirow{5}{*}{0.24} \\
\hline PrA2 & $0.851(23.91)$ & & & & & & \\
\hline PrA3 & 0.714 (11.38) & & & & & & \\
\hline PrA4 & $0.764(10.93)$ & & & & & & \\
\hline PrA5 & $0.814(25.32)$ & & & & & & \\
\hline \multicolumn{8}{|c|}{ Brand advantage $(B r A)$} \\
\hline BrA1 & $0.886(24.15)$ & \multirow{3}{*}{0.72} & \multirow{3}{*}{0.81} & \multirow{3}{*}{0.88} & \multirow{3}{*}{0.72} & \multirow{3}{*}{0.64} & \multirow{3}{*}{0.43} \\
\hline BrA2 & $0.912(48.45)$ & & & & & & \\
\hline $\mathrm{BrA3}$ & $0.757(13.66)$ & & & & & & \\
\hline \multicolumn{8}{|c|}{ Business Performance $(B P)$} \\
\hline BP1 & $0.719(6.89)$ & \multirow{4}{*}{0.58} & \multirow{4}{*}{0.76} & \multirow{4}{*}{0.84} & \multirow{4}{*}{0.58} & \multirow{4}{*}{0.35} & \multirow{4}{*}{0.22} \\
\hline BP2 & $0.760(9.76)$ & & & & & & \\
\hline BP3 & $0.779(11.38)$ & & & & & & \\
\hline BP4 & $0.801(18.48)$ & & & & & & \\
\hline
\end{tabular}

Note: $t>1.96$ at $p<0.05 ; t>2.58$ at $p<0.01, t>3.29$ at $p<0.001$ for two tailed tests. AVE = Average Variance Extracted.

Table 2. Second-order factor analysis, AVE, and convergence validity.

\begin{tabular}{|c|c|c|c|c|c|}
\hline Factor Names & $\begin{array}{l}\text { Factor Loadings } \\
\quad(t \text { Values })\end{array}$ & AVE & $\begin{array}{l}\text { Composite } \\
\text { Reliability }\end{array}$ & $\begin{array}{c}\text { Cronbach's } \\
\alpha\end{array}$ & Communality \\
\hline \multicolumn{6}{|l|}{ Market orientation $(\mathrm{MaO})$} \\
\hline Customer orientation $(\mathrm{Cuo})$ & $0.835(16.85)$ & \multirow{3}{*}{0.41} & \multirow{3}{*}{0.91} & \multirow{3}{*}{0.87} & \multirow{3}{*}{0.41} \\
\hline Competitor orientation $(\mathrm{Cmo})$ & $0.776(18.18)$ & & & & \\
\hline Inter-functional coordination $(\operatorname{In} C)$ & $0.859(26.94)$ & & & & \\
\hline \multicolumn{6}{|l|}{ Entrepreneurial orientation $(E n O)$} \\
\hline Competitive aggressiveness $(\mathrm{Co} A)$ & $0.891(27.53)$ & \multirow{3}{*}{0.40} & \multirow{3}{*}{0.89} & \multirow{3}{*}{0.89} & \multirow{3}{*}{0.40} \\
\hline Risk taking $(R i T)$ & $0.915(55.57)$ & & & & \\
\hline Proactiveness (Pro) & $0.882(36.01)$ & & & & \\
\hline
\end{tabular}

Note: $t>1.96$ at $p<0.05 ; t>2.58$ at $p<0.01, t>3.29$ at $p<0.001$ for two tailed tests.

For measuring CMV (common method variance) in terms of Harman's one-factor test (see Podsakoff and Organ [84]), the 37 variables for this study were entered into an exploratory factor analysis. The results of an unrotated principal component factor analysis displayed that the first factor does not account for a majority of the variance (34.948\%). In terms of the CFA (confirmatory factor analysis), it also appears that the single-factor model does not adequately fit the data, $\chi^{2} / d f=5.68$ $\left(\chi^{2}=2996.19, d f=527, p=0.00\right), \mathrm{CFI}=0.79, \mathrm{GFI}=0.58, \mathrm{AGFI}=0.52, \mathrm{RMSEA}=0.14$. These results suggest that our study findings, void of the problems associated with common method variance and with statistical interpretation, are unlikely to be disputed. The correlation analysis and discrimination analysis results are listed in Table 3. They show that our model satisfies the criteria for discriminant validity (the square root of the variance shared between a factor and the measure of AVE is greater than the correlation coefficient among the factors) [85]. The relationships between different discussion variables illustrate varied correlation types. As a result, the research model has good reliability and validity and its constructs have discriminant validity. Moreover, non-response bias does not appear to be an issue in this study since the analysis of responses from initial and later respondents shows insignificant differences. 
Table 3. Correlation analysis and discriminant validity.

\begin{tabular}{|c|c|c|c|c|c|c|c|c|c|c|}
\hline & 1. & 2. & 3. & 4. & 5. & 6. & 7. & 8. & 9. & 10. \\
\hline 1. Customer orientation $(\mathrm{Cuo})$ & 0.734 & & & & & & & & & \\
\hline 2. Competitor orientation $(\mathrm{Cmo})$ & $0.530 * *$ & 0.830 & & & & & & & & \\
\hline 3. Inter-functional coordination $(\operatorname{InC})$ & $0.609 * *$ & $0.432 * *$ & 0.848 & & & & & & & \\
\hline 4. Competitive aggressiveness $(C o A)$ & 0.180 & $0.582 * *$ & 0.164 & 0.824 & & & & & & \\
\hline 5. Risk taking $(R i T)$ & 0.068 & $0.351 * *$ & 0.130 & $0.744^{* *}$ & 0.806 & & & & & \\
\hline 6. Proactiveness (Pro) & $0.362 * *$ & $0.476^{* *}$ & $0.353 * *$ & $0.650 * *$ & $0.690 * *$ & 0.734 & & & & \\
\hline 7. Radical innovation $(R a I)$ & $0.414^{* *}$ & $0.569 * *$ & $0.447^{* *}$ & $0.581 * *$ & $0.582 * *$ & $0.603 * *$ & 0.866 & & & \\
\hline 8. Product advantage $(\operatorname{Pr} A)$ & $0.578^{* *}$ & $0.580 * *$ & $0.502 * *$ & $0.424^{* *}$ & $0.426^{* *}$ & $0.545^{* *}$ & $0.631^{* *}$ & 0.768 & & \\
\hline 9. Brand advantage $(B r A)$ & $0.485^{* *}$ & $0.489 * *$ & $0.467 * *$ & $0.502 * *$ & $0.474^{* *}$ & $0.557^{* *}$ & $0.634 * *$ & 0.770 ** & 0.848 & \\
\hline 10. Business Performance $(B P)$ & $0.302 * *$ & $0.401 * *$ & $0.371^{* *}$ & $0.447^{* *}$ & $0.426^{* *}$ & $0.649^{* *}$ & $0.391 * *$ & $0.503 * *$ & $0.599 * *$ & 0.761 \\
\hline Mean & 4.09 & 3.43 & 3.79 & 3.13 & 3.06 & 3.50 & 3.50 & 3.98 & 3.96 & 3.52 \\
\hline Std & 0.60 & 0.79 & 0.76 & 0.96 & 0.85 & 0.72 & 0.86 & 0.66 & 0.74 & 0.59 \\
\hline
\end{tabular}

Note: ** Significant at 0.01 level. Diagonal elements are the values of AVE for each latent variable. Off-diagonal elements are correlation coefficients of inter-construct. 


\subsection{Regression Models}

Before conducting the PLS SEM model, this study first discussed the test results of hypotheses using a regression analysis. The purpose of regression analysis is to clarify the importance level for those specific factors generated from two strategic orientation concepts on firms' radical innovation capability. As illustrated in the correlation matrix presented in Table 3, it appears there is no evidence of multi-collinearity among the independent variables [86] and, furthermore, the results indicate that it is appropriate to use the regression analysis. As shown in Table 4, the results of the regression Model 1 suggest that $\mathrm{Cmo}$ (competitor orientation) and IC (inter-functional coordination) add to firms' radical innovation $(\mathrm{RaI})(\mathrm{Cmo} \rightarrow \mathrm{RaI}=0.494 ; \mathrm{InC} \rightarrow \mathrm{RaI}=0.264)$. Model 2 suggests that Pro (proactiveness) has a higher positive relationship with the degree of firms' radical innovation (RN) $($ Pro $\rightarrow$ RaI $=0.386)$. Model 3 shows that radical innovation determines the product advantage $(\mathrm{RaI} \rightarrow \operatorname{PrA}=0.482)$. Regression Model 4 shows significant results for the effects of radical innovation $(\mathrm{RaI} \rightarrow \mathrm{BrA}=0.211)$ and product advantage $(\mathrm{PrA} \rightarrow \mathrm{BrA}=0.691)$ on firms' brand advantage. Model 5 shows that the brand advantage plays an important role in a firm's business performance $(\mathrm{BrA} \rightarrow \mathrm{BP}=0.418)$. Compared with brand advantage, radical innovation, and product advantage have no significant effect on business performance. Consequently, these results show partial support for $\mathrm{H} 1$ and $\mathrm{H} 2$ and strong support for $\mathrm{H} 3, \mathrm{H} 4, \mathrm{H} 6$, and $\mathrm{H} 8$. However, $\mathrm{H} 5$ and $\mathrm{H} 7$ are not supported.

Table 4. Regression analysis results of the conceptual framework.

\begin{tabular}{|c|c|c|c|c|c|}
\hline \multirow{2}{*}{ Factors } & Model 1 RaI & Model 2 RaI & Model 3 PrA & Model $4 \mathrm{BrA}$ & Model 5 BP \\
\hline & $\beta$ ( $t$ Value) & $\beta$ ( $t$ Value $)$ & $\beta$ ( $t$ Value) & $\beta$ ( $t$ Value $)$ & $\beta$ ( $t$ Value $)$ \\
\hline Customer orientation (Cuo) & $\begin{array}{l}0.047 \\
(0.279)\end{array}$ & & & & \\
\hline Competitor orientation $(\mathrm{Cmo})$ & $\begin{array}{c}0.494^{* * *} \\
(4.322)\end{array}$ & & & & \\
\hline $\begin{array}{l}\text { Inter-functional } \\
\text { coordination }(I n C)\end{array}$ & $\begin{array}{l}0.264^{*} \\
(2.079)\end{array}$ & & & & \\
\hline $\begin{array}{l}\text { Competitive } \\
\text { aggressiveness }(\mathrm{Co} A)\end{array}$ & & $\begin{array}{c}0.210 \\
(1.806)\end{array}$ & & & \\
\hline Risk taking $(R i T)$ & & $\begin{array}{c}0.187 \\
(0.178)\end{array}$ & & & \\
\hline Proactiveness (Pro) & & $\begin{array}{l}0.386^{* *} \\
(2.723)\end{array}$ & & & \\
\hline Radical innovation (RaI) & & & $\begin{array}{l}0.482^{* * *} \\
(7.453)\end{array}$ & $\begin{array}{l}0.211^{* *} \\
(2.847)\end{array}$ & $\begin{array}{l}-0.003 \\
(-0.042)\end{array}$ \\
\hline Product advantage $(\operatorname{Pr} A)$ & & & & $\begin{array}{l}0.691^{* * * *} \\
(7.142)\end{array}$ & $\begin{array}{c}0.094 \\
(0.722)\end{array}$ \\
\hline Brand advantage $(B r A)$ & & & & & $\begin{array}{l}0.418^{* * * *} \\
(3.605)\end{array}$ \\
\hline Constant & $\begin{array}{c}0.622 \\
(1.196)\end{array}$ & $\begin{array}{l}0.923^{*} \\
(2.608)\end{array}$ & $\begin{array}{l}2.292 * * * \\
(9.802)\end{array}$ & $\begin{array}{c}0.467 \\
(1.539) \\
\end{array}$ & $\begin{array}{l}1.504^{* * *} \\
(4.621)\end{array}$ \\
\hline Adjust $R^{2}$ & 0.351 & 0.418 & 0.391 & 0.620 & 0.340 \\
\hline Durbin Watson & 1.571 & 1.613 & 1.560 & 1.909 & 1.779 \\
\hline$F$ value & $16.339 * * *$ & $21.338 * * *$ & $55.554 * * *$ & $70.422 * * *$ & $15.575^{* * *}$ \\
\hline
\end{tabular}

Note: $\beta$ : unstandardized $\beta$ coefficients. ${ }^{*}$ Significant at 0.05 level; ${ }^{* *}$ Significant at 0.01 level, ${ }^{* * *}$ Significant at 0.001 level.

\subsection{Second-Order PLS SEM Analysis of the Concept Model}

The second-order PLS SEM analysis is undertaken to understand whether the factors (market orientation and entrepreneurial orientation) as perceived by managers are significant enough to influence and enhance the firms' radical innovation, which leads to a competitive advantage and improved business performance. Test criteria $Q^{2}$ (generated from the Stone-Geisser test) can be used to assess the predictive relevance of the model $[79,87]$. In this study, $Q^{2}$ is equal to 0.64 , which is greater than 0.5. Additionally, in terms of the Smart PLS method (Table 2), the $R^{2}$ values of the 
dependent variables could be used to identify the explanatory power of the structural model [87]. The resulting structural model shows a substantial $R^{2}$ of 0.40 for the product advantage, $R^{2}$ of 0.64 for brand advantage, and $R^{2}$ of 0.35 for business performance (see Table 2). All the $R^{2}$ values of other factors were greater than 0.2 . The results indicate that the model possesses predictive relevance and that the conceptual model has an explanatory power.

The results of the path analyses (see Table 5) include: (1) A firm's market orientation is positively related to the firm's level of radical innovation $(\mathrm{MaO} \rightarrow \mathrm{RaI}=0.389)$; (2) A firm's entrepreneurial orientation is positively related to the firm's level of radical innovation $(\mathrm{EnO} \rightarrow \mathrm{RaI}=0.484)$; (3) The radical innovation of a firm positively affects a firm's product advantage $(\operatorname{RaI} \rightarrow \operatorname{PrA}=0.636)$ and brand advantage (RaI $\rightarrow \mathrm{BrA}=0.217)$; (4) Product advantage affects the firm's brand advantage ( $\operatorname{PrA} \rightarrow \mathrm{BrA}=0.646) ;(5)$ Brand advantage significantly determines the firm's performance $(\mathrm{BrA} \rightarrow \mathrm{BP}=0.520)$; (6) The results of the full model demonstrate non-significant results for both the impact of the product advantage on the firm's business performance (Direct effect: $\operatorname{Pr} \mathrm{A} \rightarrow \mathrm{BP}=0.101$ ) and radical innovation on the firm's business performance (Direct effect: $\mathrm{RaI} \rightarrow \mathrm{BP}=0.012$ ) unless acquiring the strong support of the positive brand advantage (Indirect effect: PrA $\rightarrow$ BrA $\rightarrow$ BP: 0.335; Total effect: $\operatorname{PrA} \rightarrow \mathrm{BP}=0.436$; Indirect effect: $\mathrm{RaI} \rightarrow \mathrm{BrA} \rightarrow \mathrm{BP}=0.112$; Total effect: $\mathrm{RaI} \rightarrow \mathrm{BP}=0.124$ ). Therefore, the positive and significant mediating effects of the brand advantage have been identified. In terms of the PLS SEM method, Table 5 lists the path coefficients of the research model. In summation, the results of the research models using PLS SEM analysis strongly support H1, H2, H3, H4, H6, and H8 and do not support H5 and H7. Test findings of PLS SEM analysis are similar to those of the regression analysis.

Table 5. Test results of second order structural model using PLS SEM method.

\begin{tabular}{lccc}
\hline & \multicolumn{2}{c}{ Full Model } \\
& \multicolumn{1}{c}{ Mean-Original Sample } & $\boldsymbol{t}$ Statistics & Sig. \\
\cline { 2 - 4 } H1: Market orientation $\rightarrow$ Radical innovation & $0.389^{* * *}$ & 5.695 & $+\mathrm{S}$ \\
H2: Entrepreneurial orientation $\rightarrow$ Radical innovation & $0.484^{* * *}$ & 8.315 & $+\mathrm{S}$ \\
H3: Radical innovation $\rightarrow$ Product advantage & $0.636^{* * *}$ & 9.392 & $+\mathrm{S}$ \\
H4: Radical innovation $\rightarrow$ Brand advantage & $0.217^{*}$ & 2.561 & $+\mathrm{S}$ \\
H5: Radical innovation $\rightarrow$ Business performance & 0.012 & 0.119 & $+S$ \\
H6: Product advantage $\rightarrow$ Brand advantage & $0.646^{* * *}$ & 7.580 & $+S$ \\
H7: Product advantage $\rightarrow$ Business performance & 0.101 & 0.584 & \\
H8: Brand advantage $\rightarrow$ Business performance & $0.520^{* *}$ & 2.860 & $+S$ \\
\hline
\end{tabular}

Note: * Significant at 0.05 level; ${ }^{* *}$ Significant at 0.01 level, ${ }^{* * *}$ Significant at 0.001 level.

\section{Discussion and Conclusions}

\subsection{Discussion of Study Findings}

The research explores the theoretical bases and interactive relationships of the various dimensions through an analysis of questionnaire results containing the viewpoints of the C\&C industry respondents. Given the social commentary on firms' strategic thinking and innovation types, this study suggests that it would be valuable for firms to consider the application of strategic orientation features developed by this study for developing radical innovations, competitive advantages, and performances in their business operations. Differences in strategic orientation, radical innovation, and competitive advantages (product, brand) in firms may constitute complicating factors for a C\&C firm's business performance. Overall, based on the distinct product and brand features, companies that are informed of consumers, competitors, or partners' perceptions of companies may be better equipped for developing strategies to introduce radical innovation modes or perceptions of expertise among their target markets. 
The major findings of this study indicate a positive outlook for firms' competitive advantage and performance based on strategic orientation and radical innovation adoption of managers within the Taiwan C\&C industry. The regression analysis results show that if companies aim to be successful through radical innovation, competitor orientation and inter-functional coordination from the market orientation and proactive activity from the entrepreneurial orientation are important drivers. In our research (Models 1 and 2 in Table 4), the most important efforts for firms are to make a commitment to coordinate the objectives and actions of various functional departments within a firm and to take advantage of prospect opportunities. These are helpful to the radical innovation outputs that a C\&C firm hopes to attain. For a competitive advantage, radical innovation is beneficial to firms' product and brand advantages. The correlation analysis (see Table 3, $\mathrm{RaI} \leftrightarrow \mathrm{BP}=0.391 * *$; $\mathrm{PA} \leftrightarrow \mathrm{BP}=0.503^{* *} ; \mathrm{BA} \leftrightarrow \mathrm{BP}=0.599^{* *}$ ) and single factor regression models show that radical innovation capability $\left(\mathrm{RaI} \rightarrow \mathrm{BP}=0.270^{* * *}\right)$, product advantage $\left(\mathrm{PA} \rightarrow \mathrm{BP}=0.453^{* * *}\right)$, and brand advantage $\left(\mathrm{BA} \rightarrow \mathrm{BP}=0.480^{* * *}\right)$ all stimulate business performance. However, if we test these three factors together, this study showed that the only brand advantage is useful in firms' business performance (Model 5 in Table 4 and the PLS SEM results in Table 5). Radical innovation and product advantages may generate business performance through the mediating effects of the brand advantage. These findings are partially consistent with Chang et al. [9] and Boso et al. [51] who found that radical innovation does not directly influence business performance.

For the PLS SEM second order analysis, the following conclusions are offered. This includes emphasis both on market orientation and entrepreneurial orientation concepts. The findings support Lassen et al. [20] and Rodriguez et al. [46]. Strategic orientations determine the results of business operations. The results of correlation analysis (see Table 3) and the PLS SEM method (see Table 5) indicate that both market orientation and entrepreneurial orientation dimensions are significantly and positively associated with radical innovation. Moreover, according to regression analysis, competitors' orientations, inter-functional coordination, and proactiveness are the focus of firms when they aim to engage in radical innovation. The extant literature on NPD also emphasizes cross-functional coordination (especially extending beyond companies to include key suppliers, users, or partners) for radical innovation [14]. Therefore, under operating processes, these three sub-factors should be emphasized if $C \& C$ enterprises seek the success of radical innovation. Radical innovation is the source of competitive advantages, which is consistent with Zhang et al. [15] and Naidoo [18]. Since competitors can imitate well, when a new product enters the market, imitations quickly appear. Therefore, in the cultural and creative industry, to obtain a competitive advantage, it is important to make good use of radical innovation capabilities. Reid et al. [88] prove that technology vision for radical innovation has a positive impact on technical competitive advantages (e.g., innovation technical quality, innovation value to organization, and perceived as superior to competitors), early success with customers (e.g., acceptance by early customers, satisfaction of early customers, level of satisfaction is better than existed ones, etc.), and ability to attract capital. Radical innovations are, therefore, sources of competitive advantages in the industry and should be pursued by top management $[8,39]$. In radical innovation, enterprisers who can proactively react to customer responses, cultivate new customers, and build superior brands can alter their competitive landscape. Researchers have found that brand advantage has a critical role in strong performance $[15,29]$. Most $C \& C$ entrepreneurs are confident in the advantages of their products (mean $=3.98$ in Table 3 ) and most adopt moderate levels of radical innovation (mean $=3.50$ in Table 3 ). These two factors, therefore, have no significant effect on firm operating performance. However, brand advantage significantly and positively mediates both the effects of product advantage and firms' radical innovation level on their business performance. The greater the brand advantage, the easier it will be for consumers to identify, remember, and find the advantages of products. Therefore, the efforts of radical innovation will pay off in better business performance. Consequently, if a $C \& C$ firm wants to retain sustainability in its business field and keep ahead of its competitors, the effective development of a C\&C firm's strategic orientations, 
organizational capability (e.g., radical innovation), and competitive advantages (e.g., product and brand advantage) are rather important.

\subsection{Management Implications and Theory Contributions}

Despite distinctive contributions, most of these theories imply that firms expand into innovation capabilities in terms of their strategic concern. Based on the findings of this study, we offer several management implications. When considering the integration viewpoint of strategic orientations, regression analysis and PLS SEM suggest that C\&C enterprises should respond rapidly to competitors' strategies, integrate functional departments, commit to learning new knowledge and new technologies, pursue a specific prospective vision, and surge ahead of the competition in their industry in order to enhance radical output. Moreover, according to the respondents, if a firm's product has good sales, then imitators will emerge. Therefore, the radical innovation capability is important for $C \& C$ firms due to its ability to help C\&C firms to garner consumers' insights and obtain satisfactory volume. This means C\&C firm success is based on the integrative capability of both market orientation and entrepreneurial orientation. When considering the myth of customer orientation, $C \& C$ entrepreneurs may interact with customers who buy products. Observing the personal characteristics of customer and the reasons customers make purchases can help firms understand customer needs. However, according to our regression models (see Table 4), customer orientation has little impact on radical innovation when compared to inter-functional coordination and competitor orientation. Customers usually expect products that go beyond customers' imagination. According to the findings, among market orientation factors, coordinating different functional departments and understanding competitors' strategies are more valuable than customer orientation. These are important issues because functional department coordination has a significant effect on C\&C firms' success in operational radical innovation capability in the $\mathrm{C} \& \mathrm{C}$ industry. Moreover, it is important for $\mathrm{C} \& \mathrm{C}$ managers to understand where to focus their efforts and resources in terms of capturing competitors' direction (for surpassing, imitating, or innovating purposes in C\&C markets) so that they are able to achieve the expected level of radical innovation.

Competitive aggressiveness has no significant effect in this study likely due to most C\&C managers focusing on growth and creating a friendly commercial atmosphere. According to correlation analysis, aggressive competitiveness and risk-taking are moderately positively associated with the feature of radical innovation. For regression analysis (see Model 2 in Table 4), the $\beta$ coefficients are not significant, but is nearly significantly positive to the enterprises' level of radical innovation. This phenomenon displays that, in addition to possessing a prospective nature, having an aggressive posture to take market share from competitors and "undo-the-competitors" and taking on high-return high-risk projects are useful to enterprises' level of radical innovation. Aside from product design and manufacturing process development, new sales channels are worthy of consideration. This study suggests that $C \& C$ entrepreneurs integrate various business models (pure real store, pure virtual business model, or the integration of virtual and real channels) to increase business scale and sales. Establishing team goals, increasing the courage to develop new products, importing new technology, actively seeking new opportunities from cross-industrial cooperation, undertaking risk-taking action, working beyond competitors, and taking action (announcing new products, exploiting new opportunities) ahead of competitors will help C\&C enterprises move to a new stage. According to correlation analysis (see Table 3), radical innovation, product advantage, and brand advantage are positively associated with a C\&C firm's performance. In terms of regression (see Model 5 in Table 4) and PLS analyses results (see Table 5), brand advantage is a rather important driver to $C \& C$ firms performance. The positive and significant mediating effects of brand advantage on the effects of radical innovation and product advantage on $C \& C$ firms' performance are also verified. For instance, if a C\&C firm wants to explore what certain process factors improve or hinder the influence of success drivers (e.g., radical innovation or product advantage), brand advantage is a key determinant. In the survey process, when talking about the advantages, most 
C\&C entrepreneurs are confident regarding their product features (characteristics and design sense, reliability and stability, and product's ability to highlight the personality of consumer) and adopt a notable radical innovation level. However, when discussing brand recognition, there are differences among C\&C entrepreneurs. The greater the investment is in brand features, the better is the return. For instance, among numerous ceramics stores and manufacturers in Yingge of New Taipei City, Tai-Hwa Pottery (see http:/ / www.tai-hwa.com/taihwacart/) make great efforts to establish brand features for increasing its degree of being internationally famous. Moreover, in addition to promoting its own brand, Jafon-art (another famous art store located in Yingge that offers two types of art products: ceramics and sculpture arts; see http:/ / www.jafon-art.com) also promotes the personnel brands of art designers (e.g., Buddhist sculpture art of Jen Eng Hsiao) in its store. Wrong gallery (store located in Huashan C\&C Industrial Park of Taipei City, see http:/ /wronggalleries.com/taipei/) is an art broker and, besides selling art products, the owner also makes great efforts to enhance the degree of eminence for artists in terms of various art exhibitions or activities. The establishment of brand features is done not only via the aspect of enterprises but also through art designers themselves. Therefore, in addition to unique product advantages and radical innovation adoption, the brand advantage should be emphasized and should be the focus and target of the $C \& C$ enterprisers. Brand advantage is a key to the business performance of $C \& C$ entrepreneurs.

In conclusion, the $C \& C$ industry needs more innovation and more risk-taking features than other household industries. Gaining a sustainable competitive advantage and superior business performance are functions of the resources and capabilities that a firm brings to its competition effort [89]. Technological innovation is an important force when firms seek sustainable development [90]. Strategic orientation factors from market orientation and entrepreneurial orientations are worth incorporating into the organizational cultures, employees, and top management of C\&C firms. To build both product and brand advantages, $C \& C$ entrepreneurs should develop radical innovation processes (introduce products radically, offer more radical features, and radically change customer ways) in their daily work environment. Currently, in Taiwan, cultural and creativity products have become integrated into consumers' food, clothing, and living environments. Firms of cultural and creative industry in Taiwan have also made an effort to diversify $C \& C$ products. They announce that art products are no longer luxury or noble products. They can also be low priced but high quality and close to consumers' daily life. With such potential market opportunity of cultural and creative products, it is worthwhile for C\&C firm managers to cultivate sales and involve following the new trend. This study, therefore, contributes to the business strategy theory by demonstrating the utility of a model, which integrates aspects of the strategic orientation concept, RBV, and NPD. These include market orientation and entrepreneurial orientation, the interdependent and dependent factors of $C \& C$ enterprisers are referred to in innovation theory [61] and in competitive advantage and the performance concept $[65,66]$. The research framework in this study represents an integrated approach that can be considered by industry managers when establishing management mechanisms for radical innovation cultivation and performance improvement. Furthermore, using the responding $C \& C$ firms' strategic orientation, innovation, and competitive advantage-related conceptualization and practice, the research raises important issues about management patterns in Taiwanese C\&C firms. In summation, this research contributes toward the extant literature and the study findings can be used and referenced by top management teams in the $C \& C$ industry to strategically enhance their radical innovation capability and utilize product and brand advantages in order to achieve an improved performance.

\subsection{Limitation and Future Research}

Despite the robustness of the study findings, there are several limitations. The findings lack generalizability given the small sample. However, most respondents were directors, marketers, designers, managers, or senior employees and their responses form a useful reference. Furthermore, in practice, some researchers indicate that SMEs in developing markets have very little opportunity for radical innovation because of their low infrastructure support and are mostly concerned with imitative 
or incremental innovations. However, according to OECD [51], SMEs or new market entrants love to adopt radical innovations in their market space. In this study in Taiwan, based on the support by the Taiwanese government, $C \& C$ firms try to adopt moderate radical innovation (mean $=0.35$ ) in their business models and, in so doing, obtain satisfactory outcomes. As set out in the research framework, Hypothesis 6 ( $\operatorname{PrA} \rightarrow \mathrm{BrA}$ ) may raise concerns regarding the inverse relationship, which means a firm's brand advantage supports product advantage especially in the case of enterprises with radical innovation (e.g., Apple, Spotify, etc.). Associated innovation features and brand advantages (e.g., visual shape or logo) could enhance consumer recognition for product advantage. Future research may further explore managerial practices in relation to the bidirectional relationship between product advantage and brand advantage in order to offer a more nuanced contribution to the theory.

Based on the literature review, the linear relationships between the discussion factors have been explored in our study. The research results display the relationship presented in Hypotheses 3 to 5 $(\mathrm{RaI} \rightarrow \operatorname{PrA} ; \mathrm{RaI} \rightarrow \mathrm{BrA} ; \mathrm{RaI} \rightarrow \mathrm{BP})$ as dependent on the presence of the positive relationship presented in Hypothesis $1(\mathrm{MaO} \rightarrow \mathrm{RaI})$ and Hypothesis $2(\mathrm{EnO} \rightarrow \mathrm{RaI})$. Future research could also explore the other possible conceptual links of Hypotheses 3-5 by investigating whether the strategic orientation of enterprises exhibit negative or non-effects in relation to their radical innovation capabilities. Moreover, future research could explore how other combinations of strategic orientation by enterprises determine their radical innovation capability and explain how this capability affects or influences the firms' competitive advantages and performance. Lastly, the study results show that the application of strategic orientation models is useful in terms of a firm's radical innovation and competitive advantage to influence performance in specific markets such as the Taiwanese C\&C market. Future research can explore additional organizational features such as leadership or the organizational climate and add more dimensions for comparison such as industrial properties or consumer features or other factors or test the framework using other industrial practices or developing economic markets to generalize the model.

Acknowledgments: The author acknowledges and is grateful for the financial support (MOST: 103-2410-H-141-003-) provided by the Ministry of Science and Technology, Taiwan. The author would also like to thank reviewers at the Sustainability for helpful comments on previous versions of this article. Finally, the author acknowledges the excellent efforts of research assistants on conducting the survey for this study.

Conflicts of Interest: The author declares no conflict of interest.

\section{Appendix A. Questionnaire Development in This Study}

\section{Customer orientation $[31,35]$}

Cuo1: Competitive advantage of our firm is based on understanding customer need.

Cuo2: Our firm measures customer satisfaction systematically and frequently.

Cuo3: Our firm pays close attention to after sales service.

Cuo4: Our firm constantly monitors the level of commitment and orientation to serving customer needs.

\section{Competitor orientation $[31,32]$}

Cmo1: Our firm responds rapidly to competitors' actions.

Cmo2: Our top management regularly discusses competitors' strengths, weaknesses, and strategies.

Cmo3: Customers are targeted when our firm has an opportunity for a competitive advantage.

Inter-functional coordination [31,32,35]

Inc1: All of our managers understand how everyone in our business can contribute to creating customer value.

Inc2: Our firm emphasizes functional integration in strategy.

Inc3: Information about customers is freely communicated throughout our organization.

Inc4: Business functions within are integrated to serve the target market need. 
Competitive aggressiveness [37,38]

CoA1: Our firm tries hard to take market share from competitors.

CoA2: Our firm typically adopts a very competitive "undo-the-competitors" posture.

CoA3: Our firm is very aggressive and intensely competitive.

Risk taking [38,39]

RiT1: In our firm, many people want to take risks.

RiT2: Our firm prefers high risk projects with a high return.

RiT3: Our firm thinks that bold and wide-ranging acts are needed to achieve our goals.

RiT4: Our firm adopts risk taking decisions when facing uncertainty.

Proactiveness $[39,40]$

Pro1: Our firm tries out marketing, fundraising programs, and new opportunity continuously.

Pro2: Our firm intends to get into markets before our competitors.

Pro3: Our firm does things which our competitors then respond to.

Pro4: Our firm is typically ahead of the competition in presenting new products or procedures.

Radical innovation [61]

RaI1: Compared with competitors, our firm introduces new products that are more radically new to the market (e.g., adopting new technology).

RaI2: Compared with competitors, our firm introduces new products that offer more radical features (e.g., adopting new design or new elements).

RaI3: Compared with competitors, our firm introduces new products that require radically changes in the customer's way of using them.

Product advantage [73]

PrA1: Our products offer unique features/attributes to customers than competing products.

PrA2: Our products are superior to competing products.

PrA3: Our products are superior in technical performance than competing products.

PrA4: Our products offer benefits (specific features and styles) that are not found in competing products.

PrA5: Our products are of higher quality than competing products.

Brand advantage [29]

BrA1: Our firm has a strong reputation than competitors.

BrA2: Compared with competitors, our firm reaches the desired brand image in the market.

BrA3: Our firm has built a strong customer brand loyalty than competitors.

Business Performance $[65,66]$

BP1: Compared with competitors, our firm has achieved high sales goal.

BP2: Compared with competitors, our firm has achieved high satisfaction on profit goal.

BP3: Our firm has achieved higher profit than competitors.

BP4: Our firm has achieved better sales than competitors.

\section{References}

1. Porter, M. Competitive Advantage of Nations: Creating and Sustaining Superior Performance; Free Press Edition: New York, NY, USA, 2011.

2. Hill, C.W.L.; Schilling, M.A.; Jones, G.R. Strategic Management: An Integrated Approach: Theory \& Cases; Cengage Learning: Boston, MA, USA, 2016.

3. Nayyar, P.R. Information asymmetries: A source of competitive advantage for diversified service firms. Strateg. Manag. J. 1990, 11, 513-519. [CrossRef] 
4. Bharadwaj, S.G.; Varadarajan, P.R.; Fahy, J. Sustainable competitive advantage in service industries: A conceptual model and research propositions. J. Mark. 1993, 57, 83-99. [CrossRef]

5. Shih, T.Y. The determinate effects of competences and decision process factors on firms internationalization. Serv. Ind. J. 2010, 30, 2329-2350. [CrossRef]

6. Barney, J.B. Firm Resources and Sustained Competitive Advantage. J. Manag. 1991, 17, 99-120. [CrossRef]

7. Saranga, H.; George, R.; Beine, J.; Arnold, U. Resource configurations, product development capability, and competitive advantage: An empirical analysis of their evolution. J. Bus. Res. 2018, 85, 32-50. [CrossRef]

8. Salavou, H.; Lioukas, S. Radical product innovations in SMEs: The dominance of entrepreneurial orientation. Creat. Innov. Manag. 2003, 12, 94-108. [CrossRef]

9. Chang, W.; Franke, G.R.; Butler, T.D.; Musgrove, C.F.; Ellinger, A.E. Differential mediating effects of radical and incremental innovation on market orientation-performance relationship: A Meta-Analysis. J. Mark. Theory Pract. 2014, 22, 235-250. [CrossRef]

10. Slater, S.F.; Mohr, J.J.; Sengupta, S. Radical product innovation capability: Literature review, synthesis, and illustrative research propositions. J. Prod. Innov. Manag. 2014, 31, 552-566. [CrossRef]

11. Chen, C.K.; Reyes, L. A quality management approach to guide the executive management team through the product/service innovation process. Total Qual. Manag. Bus. 2017, 28, 1003-1022. [CrossRef]

12. Lin, L.H. Process and product innovation in virtual organisations: An investigation of Taiwanese information firms. Total Qual. Manag. Bus. 2012, 23, 1061-1072. [CrossRef]

13. Seo, Y.W.; Kim, Y.S.; Kim, D.; Yu, Y.M.; Lee, S.H. Innovation patterns of manufacturing and service firms in Korea. Total Qual. Manag. Bus. 2016, 27, 718-734. [CrossRef]

14. Story, V.; O'Malley, L.; Hart, S.; Saker, J. The development of relationships and networks for successful radical innovation. J. Consum. Behav. 2008, 7, 187-200. [CrossRef]

15. Zhang, H.; Ko, E.; Lee, E. Moderating effects of nationality and product category on the relationship between innovation and customer equity in Korea and China. J. Prod. Innov. Manag. 2013, 30, 110-122. [CrossRef]

16. Gehani, R.R. Corporate brand value shifting from identity to innovation capability: From Coca-Cola to Apple. J. Technol. Manag. Innov. 2016, 11, 11-20. [CrossRef]

17. Xin, J.Y.; Yeung, A.C.; Cheng, T.C.E. Radical innovations in new product development and their financial performance implications: An event study of US manufacturing firms. Oper. Manag. Res. 2008, 1, 119-128. [CrossRef]

18. Naidoo, V. Firm survival through a crisis: The Influence of market orientation, marketing innovation and business strategy. Ind. Mark. Manag. 2010, 39, 1311-1320. [CrossRef]

19. Wu, Y.C.; Lin, B.W.; Chen, C.J. How do internal openness and external openness affect innovation capabilities and firm performance? IEEE Trans. Eng. Manag. 2013, 60, 704-716. [CrossRef]

20. Lassen, A.H.; Gertsen, F.; Riis, J.O. The nexus of corporate entrepreneurship and radical innovation. Creat. Innov. Manag. 2006, 15, 359-372. [CrossRef]

21. Tellis, G.J.; Prabhu, J.C.; Chandy, R.K. Radical innovation across nations: The preeminence of corporate culture. J. Mark. 2009, 73, 3-23. [CrossRef]

22. Yu, L. Measuring the culture of innovation. MIT Sloan Manag. Rev. 2007, 48, 7.

23. Chang, C.H. The Influence of corporate environmental ethics on competitive advantage: The mediation role of green innovation. J. Bus. Ethics 2011, 104, 361-370. [CrossRef]

24. DCMS. Creative Industries Mapping Document; Department for Culture, Media and Sport: London, UK, 1998.

25. Caves, R.E. Creative Industries: Contracts between Art and Commerce (No. 20); Harvard University Press: Cambridge, MA, USA, 2000.

26. Hesmondhalgh, D. The Cultural Industries; Sage Publications Ltd.: Thousand Oaks, CA, USA, 2013.

27. Ministry of Culture. Development Law of Cultural and Creative Industries. Ministry of Culture: Taiwan, 2000. Available online: http://law.moc.gov.tw/law/NewsContent.aspx?id=14 (accessed on 21 February 2018).

28. Chou, C. Organizational Orientations, Industrial Category, and Responsible Innovation. Sustainability 2018, 10, 1033. [CrossRef]

29. Laukkanen, T.; Nagy, G.; Hirvonen, S.; Reijonen, H.; Pasanen, M. The effect of strategic orientations on business performance in SMEs: A multigroup analysis comparing Hungary and Finland. Int. Mark. Rev. 2013, 30, 510-535. [CrossRef] 
30. Kohli, A.K.; Jaworski, B.J. Market orientation: The construct, research propositions, and managerial implications. J. Mark. 1990, 54, 1-18. [CrossRef]

31. Guo, C.; Wang, Y. How manufacturer market orientation influences b2b customer satisfaction and retention: Empirical investigation of the three market orientation components. J. Bus. Ind. Mark. 2015, 30, 182-193. [CrossRef]

32. Tse, A.C.; Sin, L.Y.; Yau, O.H.; Lee, J.S.; Chow, R. A Firm's role in the marketplace and the relative importance of market orientation and relationship marketing orientation. Eur. J. Mark. 2004, 38, 1158-1172. [CrossRef]

33. Day, G.S.; Nedungadi, P. Managerial Representations of competitive advantage. J. Mark. 1994, 58, 31-44. [CrossRef]

34. Huang, S.K.; Wang, Y.L. Entrepreneurial orientation, learning orientation, and innovationin small and medium enterprises. Procedia Soc. Behav. Sci. 2011, 24, 563-570. [CrossRef]

35. Zhang, J.; Duan, Y. Empirical study on the impact of market orientation and innovation orientation on new product performance of Chinese manufacturers. Nankai Bus. Rev. Int. 2010, 1, 214-231. [CrossRef]

36. Miller, D.; Friesen, P.H. Innovation in conservative and entrepreneurial firms: Two models of strategic momentum. Strateg. Manag. J. 1982, 3, 1-25. [CrossRef]

37. Cho, Y.S.; Jung, J.Y. The relationship between metacognition, entrepreneurial orientation, and firm performance: An empirical investigation. Acad. Entrepreneurship J. 2014, $20,71$.

38. Lee, S.M.; Lim, S. Entrepreneurial orientation and the performance of service business. Serv. Bus. 2009, 3, 1-13. [CrossRef]

39. Hakala, H.; Kohtamäki, M. Configurations of entrepreneurial-customer-and technology orientation: Differences in learning and performance of software companies. Int. J. Entrepreneurial Behav. Res. 2011, 17, 64-81. [CrossRef]

40. Giraud Voss, Z.; Voss, G.B.; Moorman, C. An empirical examination of the complex relationships between entrepreneurial orientation and stakeholder support. Eur. J. Mark. 2005, 39, 1132-1150. [CrossRef]

41. Li, C.R.; Lin, C.J.; Chu, C.P. The nature of market orientation and the ambidexterity of innovations. Manag. Decis. 2008, 46, 1002-1026. [CrossRef]

42. Cai, L.; Liu, Q.; Zhu, X.; Deng, S. Market orientation and technological innovation: The moderating role of entrepreneurial support policies. Int. Entrepreneurship Manag. J. 2015, 11, 645-671. [CrossRef]

43. Serna, M.D.C.M.; Guzman, G.M.; Castro, S.Y.P. The relationship between market orientation and innovation in Mexican manufacturing SME's. Adv. Manag. Appl. Econ. 2013, 3, 125-137.

44. Gatigono, H.; Xuereb, J.M. Strategic orientation of the firm and new product performance. J. Mark. Res. 1997, 34, 77-90. [CrossRef]

45. Zhai, Y.M.; Sun, W.Q.; Tsai, S.B.; Wang, Z.; Zhao, Y.; Chen, Q. An empirical study on entrepreneurial orientation, absorptive capacity, and SMEs' innovation performance: A sustainable perspective. Sustainability 2018, 10, 314. [CrossRef]

46. Rodriguez, C.M.; Wise, J.A.; Martinez, C.R. Strategic capabilities in exporting: An examination of the performance of Mexican firms. Manag. Decis. 2013, 51, 1643-1663. [CrossRef]

47. Dewar, R.D.; Dutton, J. The adoption of radical and incremental innovations: An empirical analysis. Manag. Sci. 1986, 32, 1422-1433. [CrossRef]

48. Chandy, R.; Tellis, G. Organizing for Radical product innovation: The overlooked role of willingness to cannibalize. J. Mark. Res. 1998, 35, 474-487. [CrossRef]

49. Song, M.; Thieme, J. The role of suppliers in market intelligence gathering for radical and incremental innovation. J. Prod. Innov. Manag. 2009, 26, 43-57. [CrossRef]

50. Govindarajan, V.; Kopalle, P.K.; Danneels, E. The effects of mainstream and emerging customer orientations on radical and disruptive innovations. J. Prod. Innov. Manag. 2011, 28, 121-132. [CrossRef]

51. OECD. Radical and Incremental Innovation. The Innovation Policy Platform 2013. Available online: https:/ / www.innovationpolicyplatform.org/content/radical-and-incremental-innovation (accessed on 20 February 2018).

52. Schumpeter, J. Capitalism, Socialism, and Democracy; Harper: New York, NY, USA, 1942.

53. Song, X.M.; Montoya-Weiss, M.M. Critical development activities for really new versus incremental products. J. Prod. Innov. Manag. 1998, 15, 124-135. [CrossRef]

54. Hurley, R.F.; Hult, T.M. Innovation, market orientation, and organizational learning: An integration and empirical examination. J. Mark. 1998, 62, 42-54. [CrossRef] 
55. Tangkit, K.; Panjakajornsak, V. The radical innovation affecting competitive advantage of the Thai furniture industry. In Proceedings of the Management and Innovation Technology International Conference (MITicon 2016), Chonburi, Thailand, 12-14 October 2016; pp. MIT-204-MIT-208.

56. Buisson, B.; Daidj, N. Explaining successful radical innovations with effectuation. In Proceedings of the XXVIe Conférence Internationale de Management Stratégique, Lyon, France, 7-9 June 2017; pp. 1-24.

57. McDermott, C.M.; O'Connor, G.C. Managing radical innovation: An overview of emergent strategy issues. J. Prod. Innov. Manag. 2002, 19, 424-438. [CrossRef]

58. Lengler, J.F.B.; Jimenez, D.J.; Pontifícia, M.G.P.; Cegarra-Navarro, J.G.; Sampaio, C.H. Learning orientation and radical innovation as antecedents of business performance. In Cultural Perspectives in a Global Marketplace; Springer: Cham, Switzerland, 2015; pp. 15-16.

59. Rosenbusch, N.; Brinckmann, J.; Bausch, A. Is innovation always beneficial? A meta-analysis of the relationship between innovation and performance in SMEs. J. Bus. Ventur. 2011, 26, 441-457. [CrossRef]

60. Boso, N.; Story, V.M.; Cadogan, J.W.; Annan, J.; Kadić-Maglajlić, S.; Micevski, M. Enhancing the sales benefits of radical product innovativeness in internationalizing small and medium-sized enterprises. J. Bus. Res. 2016, 69, 5040-5045. [CrossRef]

61. Cheng, C.C.; Shiu, E.C. The inconvenient truth of the relationship between open innovation activities and innovation performance. Manag. Decis. 2015, 53, 625-647. [CrossRef]

62. Chiao, Y.C.; Yang, K.P.; Yu, C.M.J. Performance, internationalisation, and firm-specific advantages of SMEs in a newly-industrialized economy. Small Bus. Econ. 2006, 26, 475-492. [CrossRef]

63. Powell, T.C.; Dent-Micallef, A. Information technology as competitive advantage: The role of human, business, and technology resources. Strateg. Manag. J. 1997, 18, 375-405. [CrossRef]

64. Shih, T.Y. An empirical study of food and beverage chains' internationalisation: Advancing intangible resource theory and research. Eur. J. Int. Manag. 2017, 11, 660-687. [CrossRef]

65. Lau, A.K.; Yam, R.C.; Tang, E.P. Supply chain product co-development, product modularity and product performance: Empirical evidence from Hong Kong manufacturers. Ind. Manag. Data. Syst. 2007, 107, 1036-1065. [CrossRef]

66. Kim, N.; Shin, S.; Min, S. Strategic marketing capability: Mobilizing technological resources for new product advantage. J. Bus. Res. 2016, 69, 5644-5652. [CrossRef]

67. Almor, T.; Hashai, N.; Hirsch, S. The product cycle revisited: Knowledge intensity and firm internationalization. Manag. Int. Rev. 2006, 46, 507-528. [CrossRef]

68. Li, T.; Calantone, R.J. The impact of market knowledge competence on new product advantage: Conceptualization and empirical examination. J. Mark. 1998, 13-29. [CrossRef]

69. Wah, S.S.; Meng, M.T.C. The effects of agency costs among interfirm alliances: A study of Singapore smalland medium-sized enterprises (SMEs) in China. Int. J. Manag. 2011, 28, 379-390.

70. Hua, S.Y.; Wemmerlöv, U. Product change intensity, product advantage, and market performance: An empirical investigation of the PC industry. J. Prod. Innov. Manag. 2006, 23, 316-329. [CrossRef]

71. Doyle, P. Building successful brands: The strategic options. J. Consum. Mark. 1990, 7, 5-20. [CrossRef]

72. Lee, J.; Nguyen, M.J. Product attributes and preference for foreign brands among Vietnamese consumers. J. Retail. Consum. Serv. 2017, 35, 76-83. [CrossRef]

73. Lee, Y.K.; Park, J.W. Impact of a sustainable brand on improving business performance of airport enterprises: The case of Incheon International Airport. J. Air Transp. Manag. 2016, 53, 46-53. [CrossRef]

74. Kam-Sing Wong, S. The Influence of green product competitiveness on the success of green product innovation: Empirical evidence from the Chinese electrical and electronics industry. Eur. J. Innov. Manag. 2012, 15, 468-490. [CrossRef]

75. Su, Y.M. Analysis of the Pricing Strategy of Cultural Commodities. Taiwan Cultural Creative Industries, Ministry of Culture. Available online: http:/ / cci.culture.tw/cht/index.php?code=list\&flag=detail\&ids=57\& article_id=13793 (accessed on 5 July 2017).

76. Shih, T.Y.; Liu, Z.A. Wrong Gallery-A new paradigm for art space. J. Cases Inform. Technol. 2016, 18, 13-29. [CrossRef]

77. Chin, W.W.; Newsted, P.R. Structural equation modeling analysis with small samples using partial least squares. In Statistical Strategies for Small Sample Research; Hoyle, R., Ed.; Sage Publications: Thousand Oaks, CA, USA, 1999; pp. 307-341.

78. Cohen, J. Statistical Power Analysis for the Behavioral Sciences; L. Erlbaum Associates: Hillside, NJ, USA, 1998. 
79. Chin, W.W. Issues and opinion on structural equation modeling. Manag. Inform. Syst. Q. 1998, 22, 7-16.

80. Goldschmidt, P.; Tan, C. A Model for the Adoption of Agent Technology. Available online: https://www.researchgate.net/profile/Peter_Goldschmidt/publication/229037081_A_model_for_ the_adoption_of_agent_technology /links/0046351a3fb95de4ae000000.pdf (accessed on 3 June 2018).

81. Henseler, J.; Ringle, C.M.; Sinkovics, R.R. The use of partial least squares path modeling in international marketing. In New Challenges to International Marketing; Emerald Group Publishing Limited: Bingley, UK, 2009; pp. 277-319.

82. Barclay, D.W.; Higgins, C.A.; Thompson, R. The partial least squares approach to causal modeling: Personal computer adoption and use as illustration. Technol. Stud. 1995, 2, 285-309.

83. Yoo, Y.; Alavi, M. Media and group cohesion: Relative influences on social presence, task participation, and group consensus. MIS Q. 2001, 371-390. [CrossRef]

84. Podsakoff, P.M.; Organ, D.W. Self-reports in organizational research: Problems and prospects. J. Manag. 1986, 12, 531-544. [CrossRef]

85. Teo, H.H.; Oh, L.B.; Liu, C.; Wei, K.K. An empirical study of the effects of interactivity on web user attitude. Int. J. Hum. Comput. Stud. 2003, 58, 281-305. [CrossRef]

86. Grapentine, T. Managing multicollinearity. Mark. Res. 1997, 9, 10.

87. Fornell, C.; Cha, J. Partial least squares. In Advanced Methods of Marketing Research; Bagozzi, R.P., Ed.; Blackwell Publishers: Oxford, UK, 1994.

88. Reid, S.E.; Roberts, D.; Moore, K. Technology vision for radical innovation and its impact on early success. J. Prod. Innov. Manag. 2015, 32, 593-609. [CrossRef]

89. Carmeli, A.; Tishler, A. The relationships between intangible organizational elements and organizational performance. Strateg. Manag. J. 2004, 25, 1257-1278. [CrossRef]

90. Zhang, Y.; Na, S.; Niu, J.; Jiang, B. The Influencing factors, regional difference and temporal variation of industrial technology innovation: Evidence with the FOA-GRNN model. Sustainability 2018, 10, 187. [CrossRef]

(C) 2018 by the author. Licensee MDPI, Basel, Switzerland. This article is an open access article distributed under the terms and conditions of the Creative Commons Attribution (CC BY) license (http:/ / creativecommons.org/licenses/by/4.0/). 